\title{
Dysbiosis in the Development of Type I Diabetes and Associated Complications: From Mechanisms to Targeted Gut Microbes Manipulation Therapies
}

\author{
Gratiela Gradisteanu Pircalabioru ${ }^{1}$, Nicolae Corcionivoschi ${ }^{2}$, , Ozan Gundogdu ${ }^{3}{ }^{(D)}$, \\ Mariana-Carmen Chifiriuc ${ }^{1,4, *}$, , Luminita Gabriela Marutescu ${ }^{1}$, Bogdan Ispas ${ }^{1}$ and Octavian Savu ${ }^{5,6}$ (i)
}

check for updates

Citation: Gradisteanu Pircalabioru, G.; Corcionivoschi, N.; Gundogdu, O.; Chifiriuc, M.-C.; Marutescu, L.G.; Ispas, B.; Savu, O. Dysbiosis in the Development of Type I Diabetes and Associated Complications: From Mechanisms to Targeted Gut Microbes Manipulation Therapies. Int. J. Mol. Sci. 2021, 22, 2763. https://doi.org/10.3390/ijms22052763

Academic Editor: Maria Pascual

Received: 10 February 2021

Accepted: 8 March 2021

Published: 9 March 2021

Publisher's Note: MDPI stays neutral with regard to jurisdictional claims in published maps and institutional affiliations.

Copyright: (C) 2021 by the authors Licensee MDPI, Basel, Switzerland. This article is an open access article distributed under the terms and conditions of the Creative Commons Attribution (CC BY) license (https:// creativecommons.org/licenses/by/ $4.0 /)$.
1 Research Institute of University of Bucharest (ICUB), 300645 Bucharest, Romania; gratiela.gradisteanu@icub.unibuc.ro (G.G.P.); lumi.marutescu@gmail.com (L.G.M.); ispasbogdan26@gmail.com (B.I.)

2 Bacteriology Branch, Veterinary Sciences Division, Agri-Food and Biosciences Institute, Belfast BT9 5PX, UK: nicolae.corcionivoschi@afbini.gov.uk

3 Faculty of Infectious \& Tropical Diseases, London School of Hygiene and Tropical Medicine, Keppel Street, London WC1E 7HT, UK; Ozan.Gundogdu@lshtm.ac.uk

4 Academy of Romanian Scientists, 050045 Bucharest, Romania

5 "N.C. Paulescu" National Institute of Diabetes, Nutrition and Metabolic Diseases, 2nd District, 020042 Bucharest, Romania; savu.octavian@gmail.com

6 Department of Doctoral School, "Carol Davila” University of Medicine and Pharmacy, 5th District, 050474 Bucharest, Romania; octavian.savu@umcd.ro

* Correspondence: carmen.chifiriuc@gmail.com

\begin{abstract}
Globally, we are facing a worrying increase in type 1 diabetes mellitus (T1DM) incidence, with onset at younger age shedding light on the need to better understand the mechanisms of disease and step-up prevention. Given its implication in immune system development and regulation of metabolism, there is no surprise that the gut microbiota is a possible culprit behind T1DM pathogenesis. Additionally, microbiota manipulation by probiotics, prebiotics, dietary factors and microbiota transplantation can all modulate early host-microbiota interactions by enabling beneficial microbes with protective potential for individuals with T1DM or at high risk of developing T1DM. In this review, we discuss the challenges and perspectives of translating microbiome data into clinical practice. Nevertheless, this progress will only be possible if we focus our interest on developing numerous longitudinal, multicenter, interventional and double-blind randomized clinical trials to confirm their efficacy and safety of these therapeutic approaches.
\end{abstract}

Keywords: microbiota; type 1 diabetes; microbiome; diet; dysbiosis

\section{Introduction}

The human gastrointestinal tract (GIT) is home to almost 1000 different bacterial species, as well as viruses and fungi. Among these, the most abundant bacterial phyla are represented by Bacteroidetes, Firmicutes, Proteobacteria and Actinobacteria [1]. The microbiota population is stabilized by the age of three and is modulated by maternal diet composition, delivery mode, early nutrition (breast-milk versus formula feeding), intake of antibiotics and environmental factors (particularly hygiene level) [2].

The microbiota thrives in the nutrient-rich GIT and, in turn, provides several benefits for the host including digestion of dietary substrates, vitamin synthesis, modulation of the immune system, and protection against enteric pathogens via competition for nutrients and production of bacteriocins/other antimicrobial metabolites (i.e., hydrogen peroxide, lactic acid, etc.). A health-promoting microbiota is characterized by a certain level of microbial abundance and diversity that are not highly affected by transient perturbations caused by infections and antibiotic treatment and is also enriched in genes involved in fermentation and biosynthesis of short-chain fatty acids (SCFAs) [3]. 
Numerous studies from the last decade have shed light on the fact that microbiota is not just a collection of microorganisms that inhabit us, but a pivotal player for our health. Imbalances in the microbiota (also known as dysbiosis) are triggered by a multitude of factors including diet, pathological conditions (i.e., inflammatory bowel disease, cancer etc.), antibiotic intake, infections, stress and other environmental factors. In contrast, microbiota is an essential contributor to the development and progression of many diseases and therefore microbiota modulation holds promise as a potential therapeutic strategy. Globally, we are facing a worrying increase in type 1 diabetes mellitus (T1DM) incidence, with disease onset at younger age [4]. Research efforts have been made in the last few years and we have a general picture of the microbiome patterns linked to T1DM. Even though these studies reveal that taxonomic changes in the microbiota of T1DM patients are quite modest, a functional depletion in short chain fatty acids (SCFAs) production is commonly encountered across various studies and population groups [5].

Nevertheless, there is a paucity in studies correlating microbiota data with other host factors (i.e., metabolome, proteome, epigenetic markers, diet, etc.) as well as translating microbial diversity information into dietary/therapeutic intervention strategies. Within this review, we briefly highlight the microbiome features identified in T1DM patients together with the current intervention strategies targeting the gut microbiota and, last but not least, we discuss the challenges and perspectives of translating microbiome data into clinical practice.

\section{Type 1 Diabetes Mellitus and the Microbiota-A Chicken and Egg Situation?}

Diabetes mellitus (DM) is a heterogeneous disease, out of which type 1 DM (T1DM) is characterized by absolute lack of insulin that mainly results from autoimmune destruction of pancreatic beta cell mass (type 1A) [6]. In several cases only, in spite of a strong inheritance (type 1B), the cause of beta cell destruction is unknown [6]. As a populationwide screening for beta cell targeting autoimmunity is not yet established, the epidemiology of T1DM is based on either plasma glucose or HbA1c criteria, and classic symptoms of hyperglycemia [6]. The incidence rates of T1DM are increasing worldwide by $1.8-5 \%$ per year [7,8], and differ extensively upon geography and different ethnic populations [9], with highest occurrence in countries from Northern Europe and Canada [10]. The explanation for this variation remains unclear, although it may be related to specific risk factors, such as genetic susceptibility (i.e., population with certain types of HLA and multiple non-HLA loci) and environmental triggers (i.e., hygiene and infections) [11].

As T1DM does not occur in many subjects harboring genetic susceptibility clearly demonstrates the importance of other determinants responsible for actual T1DM increase in incidence [12]. The environmental exposure confers an additional risk for islet targeting autoimmunity $[10,11]$. Numerous environmental triggers (i.e., viral infections, gestational infections, childhood immunization, diet, especially the timing of first introduction of food) are thought to contribute to pancreatic beta cell destruction, but the mechanisms involved remain largely unknown.

However, recent data [13] support the essential contribution of exogenous triggers to rapid increase in T1DM incidence. In this scenario, the role of human microbiota in the development of (auto)immune diseases and T1DM has recently gain higher interest, as its close relations with the immune system [14] and chronic inflammation [15], and its profound and permanent changes with environmental factors [16]. Consecutively, the dysbiosis associated with (gut) microbiota modifications raises the need to better understand its significance as contemporary or causal phenomena in T1DM [17]. Evidence of a possible link between microbiota and T1DM has emerged from several animal studies. For instance, administration of single antibiotics (i.e., vancomycin) or cocktails of antibiotics triggered microbiota changes in non-obese diabetic (NOD) mice leading to accelerated or delayed disease progression [18-22].

The causative link microbiota-T1DM was proven in murine models. It was shown that T1DM development is in close relation with the host innate immunity. Hence, interaction of 
the commensal biota with the innate immune system impacted the onset and progression of T1DM. Toll-like receptors (TLRs), are crucial players in the innate immunity and intestinal homeostasis. Importantly, microorganisms can affect autoimmunity of T1D via signaling through TLR family receptors [23-25]. Interestingly, NOD mice deficient in MyD88, an adaptor molecule for TLR signaling, did not develop T1DM under conventional SPF (specific pathogen free) conditions but this protection was abolished under germ free conditions [26]. Moreover, T1DM incidence was reduced when MyD88 deficient mice were exposed to a predefined microbiota mixture, further highlighting the close connection between the microbiome and host immunity [26].

Another way by which bacteria can impact T1DM pathogenesis is through production of short chain fatty acids (SCFAs) such as butyrate, propionate and acetate. Several research reports linked abundance of butyrate-producing species with T1DM risk [27-30]. Studies show that butyrate may exert epigenetic effects with a paramount role in T1DM such as histone acetylation in the promoter of the Foxp3 locus responsible for the differentiation of regulatory $\mathrm{T}$ cells or inhibition of histone deacetylases in macrophages [31-33]. However, current data does not elucidate whether SCFAs induce tolerance by modulating either host microbiome or inflammatory response [34].

Opposite to most previous reports [35,36], studies from recent years have shown that in the case of T1DM, microbiota changes occur prior to systemic signs of islet autoimmunity $[37,38]$. The reason for this shift may resides in that the microbiota modifications were mostly detected only by gene analysis of $16 \mathrm{~S}$ rRNA, which may not identify specific structural and/or functional characteristics potentially involved in disease progression. Later studies addressed this issue both by a specific design allowing to control for all known factors interfering for T1DM susceptibility and microbiome characteristics [38], and by longitudinal metagenomic sequencing of stool samples [37]. Regardless of geographical location, the T1DM environmental niche was shown to harbor a proinflammatory environment colonized by higher level of Bacteroidetes and low abundance of Firmicutes [39]. It has been suggested that the reduction in Firmicutes may be detrimental for the host because this phylum reunites many producers of the SCFA butyrate, known to be involved in intestinal homeostasis. Moreover, the Bacteroidetes phylum is comprised, among others, of Bacteroides and Prevotella strains [39]. Many studies have shown that T1DM is dominated by Bacteroides, a taxa correlated with intestinal inflammation whereas Prevotella, believed to be protective, is reduced [40].

Regardless of the great variability found in T1DM associated microbiota, several studies consistently reported that Bacteroides was linked to T1DM development [27,28,41-44]. Indeed, species belonging to this genus can ferment glucose and lactate to propionate, acetate, and succinate [45] while not being able to generate butyrate [46]. Butyrate is a crucial metabolite for intestinal homeostasis that stimulates mucin synthesis [47] and can also decrease gut permeability by enabling the assembly of tight junctions (TJ) [48]. In addition lactate producing bacteria, including some probiotic strains (Lactobacillus rhamnosus and L. reuteri [49], L. johnsonii N6.2 [50], L. plantarum [51], Bifidobacterium lactis [52] may synthetise butyrate [53] and, thus, strengthen the intestinal barrier function.

All these findings paint the picture for microbiota involvement in T1DM pathogenesis but, nevertheless, conclusions from animal studies need to be taken with caution [54]. Some studies reported that alterations in microbiome composition were evident prior to T1DM development $[27,28,36,55]$. However, these were prospective studies that presented a timeframe of disease progression linked to microbial dysbiosis, and to address the issue of a causal contribution of the microbiota in this ailment, intervention studies are needed.

Knowledge regarding the involvement of probiotics in this equation is still scarce. Nevertheless, early administration of probiotics during the first four weeks of life diminished the risk of beta cell autoimmunity in subjects genetically susceptible to T1DM when compared to those that received no probiotics [56]. Administration of the prebiotic oligofructose-enriched inulin in a single-center, randomized, double-blind, placebocontrolled pilot study in children with T1DM was shown to improve beta cell function and 
intestinal permeability. Nevertheless, prebiotic administration did not improve glycaemic control likely due to the small sample size analyzed [57]. Even though interventional human studies suggest a microbial involvement in T1DM, a causal relationship still cannot be inferred due to the lack of large-scale prospective studies that clearly demonstrate that microbiome changes alter T1DM risk. Future randomized controlled studies in large cohorts are still necessary. For instance, there are no human studies to address the link between antibiotic intake-microbiota changes-T1DM or between FMT-microbiota-T1DM.

\section{Translational Applications-Moving from Fundamental Research to Improved Diagnosis and Therapeutic Strategies in T1DM}

As our knowledge in the microbiome field expands, it is becoming more evident that reshaping the gut microbiota through various strategies (i.e., diet, probiotics, prebiotics, fecal transplant) holds promise in T1DM therapy in terms of halting disease progression and even prevention (Figure 1). Personalized changes in the host microbiota, customized in accordance to the host genetic background may be a powerful new approach in prevention and treatment.

Healthy

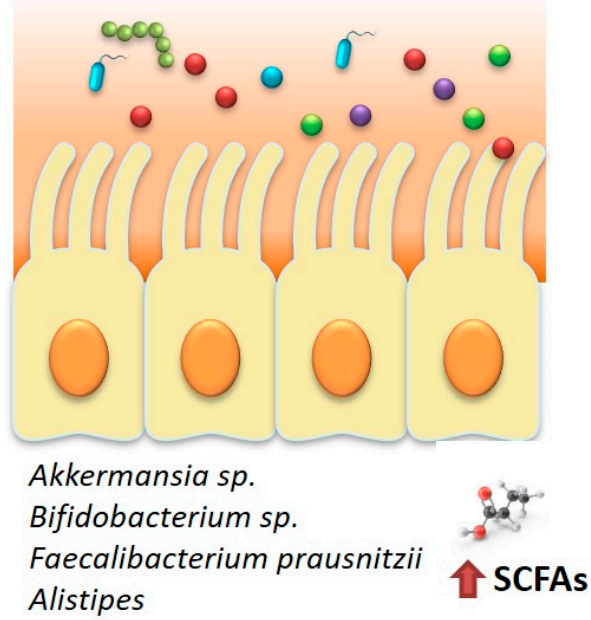

\section{T1DM}

Bacteroides : B. ovatus, B. dorei, B. longum

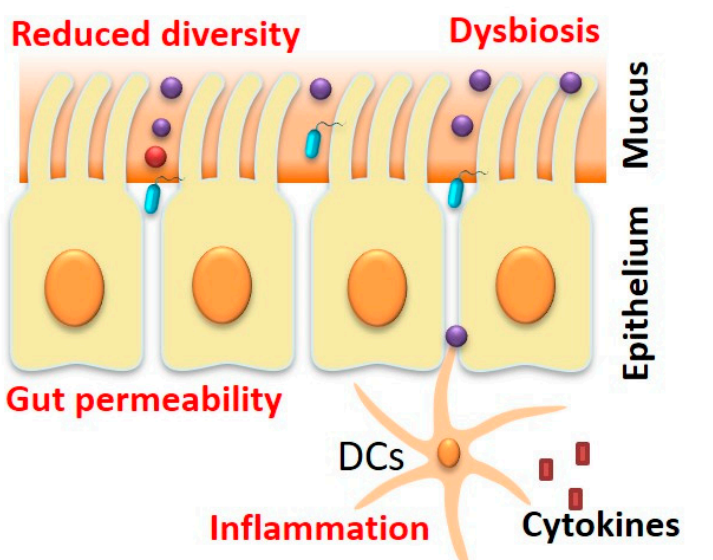

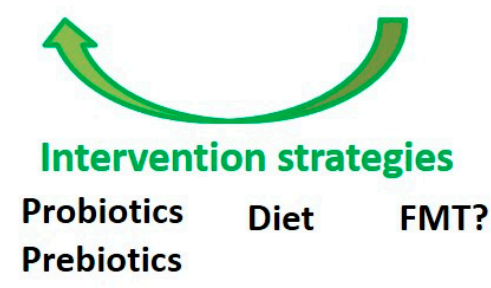

Autoimmunity

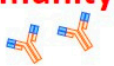

Intervention strategies

Prebiotics

Figure 1. Gut microbiota and T1DM. T1DM patients harbor a microbiota with reduced diversity enriched in Bacteroides species (B. dorei, B. ovatus, B. logum). The gut environment in T1DM is characterized by increased gut permeability, disrupted mucus barrier, inflammation and low production of SCFAs (particularly butyrate).

\subsection{Diet}

It is well established that microbiota composition is highly dependent on host diet [58]. In subjects with autoimmune diseases, microbiota suffers significant differences compared with healthy persons $[30,59,60]$. The link between diet inductors of gut dysbiosis (i.e., fat from bovine milk, protein from fresh milk or gluten) and subsequent development of T1DM has been suggested in several human studies [61-63]. The impact of dietary style on intestinal microbiota and the occurrence of T1DM is furthermore demonstrated by studies involving second generation of immigrants coming to Sweden [64]. Post-immigration occurrence of metabolic diseases in relation with diet modifications were also reported in migrants coming to U.S [65]. 
Experiments on mice have shown that a high-protein diet leads to an increased level of IGF-1 (insulin-like growth factor 1) which is correlated with a high risk of developing diabetes. Studies on mice fed with solid animal fats have revealed a greater abundance of species of the genus Bacteroides and Bilophila, while in mice fed with fish oil dominated the Bifidobacterium, Adlercreutzia, Lactobacillus, Streptococcus genera and A. muciniphila. The mice fed with lard developed inflammation in the white adipose tissue, low insulin sensitivity, TLR (Toll-like receptor) activation, as opposed to those fed with fish oil [66]. The artificial sweeteners such as saccharin, sucralose, and aspartame have been proposed as an alternative to natural sugar and promoted as healthy and without calories, although they are quite controversial and the opinions and expert opinion is divided. The consumption of artificial sweeteners has many consequences such as structural and functional alterations of the intestinal microbiome, causes glucose intolerance and determines a predisposition to diabetes [67].

Data from human and animal studies suggest that early exposure to foreign food antigens such as bovine insulin and gluten may be involved in $\beta$-cell immunity $[68,69]$. Therefore, it is not surprising that diet is also an important contributor to T1DM onset and progression. As previously mentioned, a leaky gut barrier is commonly encountered in T1DM [41]. Gluten was shown to harbor various effects in the body, starting from the intestine where it may alter microbiota composition triggering enteropathy and intestinal permeability [70]. Moreover, these effects can be modulated by a gluten free diet [71]. As revealed by animal studies, a gluten free diet may dampen the innate and adaptive immune system proving to be beneficial for the host [71]. In human T1DM, several intervention strategies have been proposed including gluten exclusion during pregnancy combined with early gluten introduction, mucosal tolerance induction to gluten as well as gluten free diets [71]. Gluten-based diets were linked to gut permeability alterations via microbiome modulation [72]. For example, taxa associated to a gluten free diet (i.e., Akkermansia sp.) were reported to impact gut permeability by regulating tight junction proteins and to be protective in case of T1DM [73].

Both animal and human studies reveal the fact that early exposure to gluten $(<3$ months in humans) raises the risk to develop islet autoimmunity [74,75]. In patients with genetic predisposition, who are positive for HLA DQ2/DQ8, gluten activates the specific T lymphocytes, leading to mucosal destruction, hyperplasia of intestinal crypts, as well as subtotal or total vilositary atrophy [76].

Though, in both celiac disease and T1DM, the effects of gluten free diet are still controversial. Hence, it was reported that in children with established T1DM and concomitant biopsy diagnosis of coeliac disease over a 10-year period, gluten-free diet significantly improved both weight, height, and BMI adjusted for age, and improved diabetes control by reducing daily insulin doses [77]. In NOD mice, gluten free diet prevents diabetes by reducing the number of caecal bacteria [78]. However, other reports did not find a significant effect $[79,80]$.

Cow's milk is another dietary factor believed to be involved in T1DM but this aspect is a subject of controversy. While some studies highlight that bovine milk proteins may be a culprit in mounting a humoral immune response leading to disease onset [81], other studies found no differences [82] or even implied that cow's milk formula has a beneficial effect against T1DM [83]. Moreover, cow's milk formula containing bovine insulin was shown to trigger an autoimmune response to insulin. In addition, a subsequent study (Finnish Dietary Intervention Trial for the Prevention of T1DM) reported that milk formula without bovine insulin reduced the risk of $\beta$-cells autoimmunity [84].

Breast milk induces dose dependent changes in the infant microbiota that correlate with specific bacteria (i.e., Bifidobacterium and Lactobacillus) transferred from maternal microbiota $[85,86]$. As for gluten, murine studies suggested that for breast milk the timing of introduction is essential for an efficient microbiome regulation of the infant's immune system [87]. Hence, it has been shown that infants that were breastfed only during first 6 months of life have developed a distinct pattern of microbiota [1]. Moreover, it is 
suggested that breast milk protects against T1DM occurrence in children with genetic predisposition [88].

Recent data [89] have shown that the occurrence of islet autoimmunity and the progression towards T1DM in genetically predisposed children was not influenced either by the age of solid food introduction or by the duration of breastfeeding. These results support previous observation showing that breastfeeding alone may interfere with T1DM occurrence $[90,91]$. Nevertheless, how and to what extent dietary factors influence T1DM pathophysiology is an important aspect that awaits future research.

Permanent dietary changes can trigger the enrichment of beneficial taxa shaping the intestinal homeostasis, but we have to highlight the paramount importance of the patient ability to adhere to certain diets. Moreover, one major challenge in this field is to decipher the high variability in individual responses to food intake. People differ greatly in their responses to diet intervention due to a wide array of factors some of which are non-foodspecific factors (sleep, meal timing and activity). Hence, dietary interventions hold promise in improving host health but their implementation should be carefully optimized using rigorous prediction algorithms.

\subsection{Probiotics-The Promises and the Unmet Needs}

Probiotics are microorganisms (bacteria, fungi) commonly regarded as safe that, when administered to a subject, promote a wide range of beneficial effects including modulation of gut microbiota and immunomodulation.

Most of the progress in understanding and developing microbiome therapeutics has emerged from rodent models. However, rodents and humans harbor fundamentally different microbiomes, so making the transition from one to another needs to be performed with caution. Several probiotics are currently being used in clinical trials to correct the dysbiosis linked toT1DM [92].

Besides the well-known lactobacilli, promising probiotics that are potent SCFA producers (especially butyrate) such as Roseburia intestinalis, Eubacterium halli and Faecalibacterium spp. can be employed in clinical trials [93]. For instance, probiotics such as B. lactis Bb12L and $L$. rhamnosus GG are currently being investigated for their protective role in a clinical study in children with newly diagnosed T1DM [72]. Notably, probiotic administration (lactobacilli and bifidobacterial species) early in life was significantly correlated with a reduced autoimmunity risk in subjects harboring an HLA-DR3/4 genotype [56]. Currently, several ongoing clinical studies are investigating the role of probiotics such as L. johnsonii, L. plantarum, L. salivarius AP-32,VSL\#3, and B. animalis subsp. lactis CP-9 in T1DM management (NCT03880760, NCT03423589, NCT03423589, NCT04141761, NCT03961854, NCT04335656). Most of these clinical studies are in the recruitment phase but, once completed, they may provide a better picture regarding the impact of probiotic supplementation on metabolic profile (blood glucose, HbA1c), systemic inflammation, host transcriptome, gut barrier function, and microbiome profile.

Even though a series of recent papers have addressed the various microbiota patterns linked to diabetes, still there is research needed to assess the impact of microbiota manipulation on development of diabetes complications [5,17,40,54,72,94-97]. Specifically, the complications triggered by diabetes can be either microvascular (nephropathy, retinopathy, and neuropathy) or macrovascular (i.e., cardiovascular disease, peripheral vascular disease, cerebrovascular accidents). In the last few years, several research groups have investigated this aspect particularly in the case of diabetic nephropathy. Indeed, gut microbiota is impaired in chronic kidney disease likely due to elevated uremia which halts intestinal barrier function triggering intestinal inflammation which in turn may disturb the renal parameters. Therefore, manipulation of gut microbiota may positively modulate the renal profiles in these patients. The results emerging from studies of probiotic use in diabetes complications are summarized in Table 1. Most of the microorganisms used in these studies belonged to the Lactobacillus and Bifidobacterium genra whereas the dosage ranged from $2 \times 10^{7}$ to $6 \times 10^{10} \mathrm{CFU} / \mathrm{g}$. The form of the probiotics varied across the studies (capsules, 
soy milk, sachets, kefir and honey). Most studies demonstrated the benefits of probiotic supplementation on diminishing inflammation, oxidative stress and on the amelioration of renal function biomarkers in patients with diabetic nephropathy.

Table 1. Studies of probiotic use in diabetes complications.

\begin{tabular}{|c|c|c|c|}
\hline Study Group Details & Treatment & Outcome & Reference \\
\hline $\begin{array}{l}\text { Diabetic nephropathy, } 44 \\
\text { subjects probiotic }(n=22) \\
\text { placebo }(n=22)\end{array}$ & $\begin{array}{l}\text { Soy milk containing } L \text {. } \\
\text { plantarum A7 adminsitered for } \\
8 \text { weeks }\end{array}$ & $\begin{array}{l}\text { Significant impact on lipid } \\
\text { profile and glomerular } \\
\text { function }\end{array}$ & $\begin{array}{c}\text { Abbasi et al., } 2017 \\
\text { [98] }\end{array}$ \\
\hline $\begin{array}{l}\text { Diabetic nephropathy, } 136 \\
\text { subjects probiotic }(n=68) \\
\text { placebo }(n=68)\end{array}$ & $\begin{array}{l}\text { L.acidophilus, L. casei, L. lactis, } \\
\text { B. bifidum, B. infantis, } B \text {. } \\
\text { longum and with a daily dose } \\
\text { of } 6 \times 10^{10} \\
12 \text { weeks }\end{array}$ & $\begin{array}{l}\text { The urea levels significantly } \\
\text { declined in the probiotic } \\
\text { group while her parameters of } \\
\text { renal profile as well as liver } \\
\text { function tests remained } \\
\text { unchanged }\end{array}$ & $\begin{array}{l}\text { Firouzi et al., } 2015 \\
\text { [99] }\end{array}$ \\
\hline $\begin{array}{c}\text { Diabetic nephropathy } \\
60 \text { subjects probiotic }(n=30) \\
\text { placebo }(n=30)\end{array}$ & $\begin{array}{c}8 \times 10^{9} \text { CFU day }^{-1} \\
\text { of probiotic supplements } \\
\text { containing } L . \\
\text { acidophilus strain ZT-L1, } \\
\text { B. bifidum } \\
\text { strain ZT-B1, L. } \\
\text { reuteri strain ZT-Lre, and } \\
\text { L. fermentum } \\
\text { strain ZT-L3 (each } 2 \times 10^{9} \text { ) } \\
12 \text { weeks }\end{array}$ & $\begin{array}{l}\text { Probiotics supplementation } \\
\text { for } 12 \text { weeks had beneficial } \\
\text { effects on glycemic control } \\
\text { and markers of } \\
\text { cardio-metabolic risk. It may } \\
\text { confer advantageous } \\
\text { therapeutic potential for } \\
\text { patients with diabetic } \\
\text { nephropathy }\end{array}$ & Mafi et al., 2018 [100] \\
\hline $\begin{array}{l}\text { Diabetic nephropathy, } \\
\text { probiotic }(n=30) \text { placebo } \\
\qquad(n=30)\end{array}$ & $\begin{array}{l}\text { L. acidophilus, } \\
\text { L. casei and } \\
\text { B. bifidum } \\
12 \text { weeks }\end{array}$ & $\begin{array}{l}\text { Probiotic supplementation for } \\
12 \text { weeks among diabetic HD } \\
\text { patients had beneficial effects } \\
\text { on the parameters of glucose } \\
\text { homeostasis and a few } \\
\text { biomarkers of inflammation } \\
\text { and oxidative stress }\end{array}$ & Soleimani et al., 2016 [101] \\
\hline $\begin{array}{c}\text { Diabetic nephropathy } \\
60 \text { subjects probiotic }(n=30) \\
\text { placebo }(n=30)\end{array}$ & $\begin{array}{c}\text { Bacillus coagulans T11 } \\
\text { (IBRCM10791) }\left(10^{8} \mathrm{CFU} / \mathrm{g}\right) \\
12 \text { weeks }\end{array}$ & $\begin{array}{l}\text { Probiotic honey consumption } \\
\text { lead to improved insulin } \\
\text { metabolism, } \\
\text { total-/HDLcholesterol, } \\
\text { plasma MDA levels, and } \\
\text { serum hs-CRP, and but did not } \\
\text { affect other metabolic profiles }\end{array}$ & $\begin{array}{l}\text { Mazruei et al., } 2019 \\
\text { [102] }\end{array}$ \\
\hline $\begin{array}{l}\text { Diabetic nephropathy, } n=48 \\
48 \text { subjects probiotic }(n=24) \\
\text { placebo }(n=24)\end{array}$ & $\begin{array}{l}200 \mathrm{~mL} / \text { day probiotic ( } L \text {. } \\
\text { plantarum A7 strain) soy milk } \\
\text { in the intervention group or } \\
\text { soy milk in the control group } \\
8 \text { weeks }\end{array}$ & $\begin{array}{l}\text { DN participants in the } \\
\text { probiotic soy milk group had } \\
\text { higher levels of GSH } \\
\text { compared to those in the soy } \\
\text { milk group. Significantly } \\
\text { increased levels of glutathione } \\
\text { reductase and glutathione } \\
\text { peroxidase were reported for } \\
\text { the probiotic group }\end{array}$ & Miraghajani et al., 2017 [103] \\
\hline $\begin{array}{l}\text { Diabetic retinopathy } \\
\text { Animal study }\end{array}$ & $\begin{array}{l}\text { L. rhamnosus administration } \\
4 \text { months }\end{array}$ & $\begin{array}{l}\text { Probiotic administration } \\
\text { reduced the intraocular } \\
\text { pressure in diabetic mice }\end{array}$ & $\begin{array}{c}\text { Home, } 2020 \\
{[104]}\end{array}$ \\
\hline
\end{tabular}


Table 1. Cont

\begin{tabular}{|c|c|c|c|}
\hline Study Group Details & Treatment & Outcome & Reference \\
\hline $\begin{array}{l}\text { Diabetes complicated by } \\
\text { coronary heart disease robiotic } \\
\text { supplements }(n=30) \text { or } \\
\text { placebo }(n=30) \text { for } 12 \text { weeks. }\end{array}$ & $\begin{array}{c}\text { Oral administration of } \\
2.5 \times 10^{9} \text { CFU/g probiotic } \\
\text { containing B. bifidum, B. lactis, } \\
\text { L. acidophilus, L. brevis, L. casei, } \\
\text { L. salivarius, L. lactis and } L \text {. } \\
\text { lactis twice a day } \\
12 \text { weeks }\end{array}$ & $\begin{array}{l}\text { Probiotic supplementation } \\
\text { significantly decreased fasting } \\
\text { plasma glucose, insulin } \\
\text { resistance and } \\
\text { total-/HDL-cholesterol ratio. } \\
\text { Probiotic administration } \\
\text { significantly increased insulin } \\
\text { sensitivity and } \\
\text { HDL-cholesterol levels } \\
\text { compared to the placebo } \\
\text { group }\end{array}$ & $\begin{array}{c}\text { Raygan et al., } 2018 \\
\text { [105] }\end{array}$ \\
\hline Diabetic mice & $\begin{array}{c}\text { L. paracasei secreting } \\
\text { Angiotensin- }(1-7) 1 \times 10^{9} \mathrm{CFU} \\
8 \text { weeks }\end{array}$ & $\begin{array}{l}\text { Probiotic treatment treatment } \\
\text { significantly lowered } \\
\text { apoptotic cell death in kidney, } \\
\text { improved diabetes-induced } \\
\text { collagen deposits in the } \\
\text { glomerular tuft and the } \\
\text { tubular epithelia in diabetic } \\
\text { mice. LP-A administration } \\
\text { also significantly improved } \\
\text { retinal gliosis, neuronal cell } \\
\text { death inflammation, and loss } \\
\text { of retinal vascular capillaries. }\end{array}$ & $\begin{array}{c}\text { Li et al., } 2018 \\
\text { [106] }\end{array}$ \\
\hline
\end{tabular}

Even though there is a high amount of research being done in the field of probiotics and their positive effects on various ailments, there are still some challenges left. Importantly, a probiotic strain needs to establish itself within the intestinal niche in order to elicit its host beneficial effects. However, to do this, the probiotic strain may have to outcompete the indigenous microbiota while being resistant to the host antimicrobial peptides. Since we know that the host microbiota varies from individual to individual, we can say that probiotic outcomes are individualized and, to some extent, unpredictable. Nevertheless, some studies advocate that establishment of a probiotic within the gut microbiota is not mandatory to elicit a beneficial effect. Therefore, while probiotics may be transient, they may modulate the microbiome via the production of beneficial metabolites including SCFAs.

Moreover, studies and clinical trials employing probiotics for treatment of T1DM (or any other disease for that matter) need to provide information regarding patient details such as age, gender, geographical location, comorbidities, medication taken, and nutrition as well as the impact of probiotics on the host metabolome (particularly SCFAs, bile acids) and immune system. Only such randomized, placebo-controlled studies may help us decipher the gut-microbiome interplay and may guide us to identify which patients may benefit from a certain probiotic or not.

\subsection{Prebiotics-Potential Adjuvants in Glycemic Control}

Prebiotics, defined as non-digestible food ingredients that modulate the microbiota by serving as nutritional substrates for the growth and multiplication of probiotics, also hold therapeutic potential. Inulin, human milk oligosaccharides, and lactulose are prebiotics that boost the growth of various probiotic strains including bifidobacteria. Current management of T1DM is based on multiple daily subcutaneous insulin injections or infusion and frequent glycaemic monitorisation. Unfortunately, it is still challenging to reach optimal glycemic control in these patients. Hence, in this scenario, adjunctive oral supplements in the shape of prebiotics may help improve glycemic control. Within this line of thought, a recent study by Ho et al. used oligofructose-enriched inulin in a randomized, placebocontrolled trial performed in T1DM children. Treatment with oligofructose enriched inulin 
was shown to harbor beneficial effects in T1DM children by significantly increasing Cpeptide levels [57]. Moreover, a randomized, placebo-controlled trial recently showed that prebiotics may positively impact glycaemic control through direct interventions on gut microbiota by prebiotic administration and subsequent reducing of intestinal permeability, thereby improving insulin sensitivity in young T1DM patients [107]. This study confirmed in children with established T1DM previous observation on obese mice [108] that reduced gut permeability involves an increased level of glucagon like peptide (GLP)-2.

Most of the studies addressing the impact of prebiotics on T1DM have been performed on animal models and so far, not many clinical trials in humans exist. Notably, an acetylated and butyrylated form of high amylose maize starch (HAMS-AB) that was shown to increase SCFAs production and to be safe and effective in disease prevention in T1DM mouse models is currently being used in a phase 3 clinical trial (NCT04114357) in children and adolescents with recently diagnosed T1DM.

\subsection{Faecal Microbiota Transplant-Solution or Potential Problem?}

Host microbiota can be also modified by faecal microbiota transplant (FMT), which involves the transfer of a 'healthy' microbiome into a recipient with dysbiosis with the purpose to restore gut homeostasis. FMT is being used successfully in treating Clostridium difficile infection, however its success in treating T1DM is largely unknown.

A recent study by de Groot et al. showed that autologous (i.e., from T1DM patients) but not homologus (i.e., from healthy donors) FMT of colon-derived microbiota into the intestine of patients with new onset T1DM lead to a prolonged residual beta cell function. One possible explanation proposed by authors is that the autologous FMT is more immunologically compatible with the host. The assumption is in line with the results of the study showing that the preservation of beta cell function by autologous FMT is T cell mediated, as CD4+ CXCR3+ and CD8+ CXCR3+ T cells were decreased differentially in the responders.

In addition, the study identifies several taxa with therapeutic potential including duodenal Prevotella spp. and S. oralis as well as faecal Desulfovibrio piger and Bacteroides stercoris [109]. Both Prevotella spp. and S. oralis were negatively correlated with the most important fasting plasma metabolite that changed upon FMT and with fasting C-peptide. Bacteroides stercoris correlated positively with Desulfovibrio piger while the latter correlated positively with another fasting plasma metabolite that changed upon FMT and with fasting C-peptide. Moreover, Desulfovibrio piger was negatively correlated with CD4+ CXCR3+ and CD8+ CXCR3+ T cells. These results suggest that taxa that changed upon FMT in subjects with T1DM has beneficial effects either by preserving beta cell function or by suppressing autoimmunity.

Nevertheless, one has to bear in mind the fact that while probiotic administration transfers few microbial species to the recipient gut, FMT conveys a mix of various microorganisms into the host, out of which some may possibly be hazardous for the recipient host. Thus, in order to consider FMT as a potent therapeutic approach, composition of the faecal microbiota for transplantation needs to be standardized prior to administration. Importantly, we still do not fully know the profile of the "perfect" donor and other problematic factors including sustainability of the procedure and risk of infection need to be dealt with.

\section{Omic Technologies-From Bench to Bedside}

Multi omics approaches are an area of active investigation that may ultimately offer opportunity for personalized treatment for many ailments. Importantly, most of the omicsbased studies on diabetes reported so far used mainly patient serum samples. Nevertheless, it is important to also look into other types of samples (i.e., fecal samples) and to correlate multi-omic approaches with the gut microbiota. Only in this way we can reconstitute the flow of information from disease parameters to causes of disease (genetic or environmental), functional consequences and treatment opportunities. 
Several research studies exist regarding multi omic analysis in case of diabetes but most of them are focused on type 2 diabetes rather than T1DM [110]. Nevertheless, transcriptomics analysis done by using microRNA (miRNA) microarray, followed by qRT-PCR (quantitative Real Time PCR) validation showed some specific features linked to T1DM. Thus, several miRNAs in peripheral blood mononuclear cells were reported to be specific to T1DM: miR-103, let-7, miR-1260, miR-130a, miR-1274, miR-150 miR-720, miR-193a-5p, miR-20b, miR-16-5p, miR-133a-3p, miR-142-5p, miR-409-5p, miR-501-3p, miR-486-5p, miR-145-3p, miR-3150-3p and miR-1271-5p, with some of them being linked to retinopathy and nephropathy [111-113].

Proteomic approaches have been used to elucidate the mechanisms of beta-cell dysfunction in diabetes. Thus, using proteomics diagnostic tools, six new T1DM autoantibodies have been identified. More specifically, these autoantibodies are against receptor type N2 (PTPRN2), protein tyrosine phosphatase, nucleoporin 50, mutL homolog 1 (MLH1), peptidyl-prolyl cis-trans isomerase-like 2 (PPIL2), mitochondrial translational initiation factor 3 (MTIF3) and pyroglutamylated RFamide peptide receptor (QRFPR) [114]. Besides autoantibodies, serum adiposity proteins and immune molecules have been linked to T1DM but their validity has yet to be studied through proteomics [115].

Even though metabolomics data may have a powerful impact on T1DM management, current therapeutic approaches revolve around targeting high glucose levels and glycosylated hemoglobin. It was reported that patients with diabetes (both type 1 and type 2) harbored elevated levels of aromatic and branched-chain essential amino acids [116] which are produced by members of the microbiota such as Escherichia coli [117]. Microbiota is closely related to the metabolomic profile as it was recently shown for type 2 diabetes in an elegant study by Nuli et al. (2019) [118]. Faecal metabolites such as protorifamycin I, matricin, and epothilone A were negatively correlated with Actinobacteria. A similar testing for the T1DM fecal metabolome awaits investigation [118].

Several reports have also linked T1DM autoimmune development with lipidomic changes. Hence, changes in the metabolomic profiles of various classes of lipids, such as triglycerides, plasma phospholipids, sphingolipids, glycerophospholipids, and cholesterol esters, within the context of T1D have been reported [116,119-121].

Since the management of all types of diabetes comprises of dietary and lifestyle interventions, future work aiming to analyze how diet impacts metabolites and the microbiome is essential.

The main advantage of using omics-based technologies is the fact they provide simultaneous detection of multiple molecules, helping to better understand and potentially treat disease. Nevertheless, there is still a lot we need to understand in order to apply a personalized treatment approach in T1DM. It is imperative to further standardize and automate these methods of analysis particularly in the case of metabolomics and proteomics in order to make efficient and reproducible high-throughput analyses. Despite the great promise of integrating big data multiomics into patient treatment, there are limitations as well as ethical considerations currently halting its large scale implementation. Beside the logistic concerns surrounding implementation of these technologies, these omic approaches are very costly and, moreover, there is a general reluctance to change in health-care systems. Unfortunately, though, there is also a fundamental lack of recognition by funding agencies of the potential for omic-guided care to improve disease outcome.

We show here that several methods to tailor the host microbiota have good potential in improving T1DM outcome. We believe that combining traditional sources of medical information (i.e., laboratory workup, patient history) with data emerging from omic technologies (i.e., microbiome, metabolome) will enable patient stratification subsequently aiding the clinician to choose the appropriate intervention strategies (diet, probiotics, fecal transplant etc.). It is imperative to make the transition from the lab to the clinic so that we can help deliver precision medicine to individual patients (Figure 2). Moreover, a patient follow-up after the intervention is crucial. 


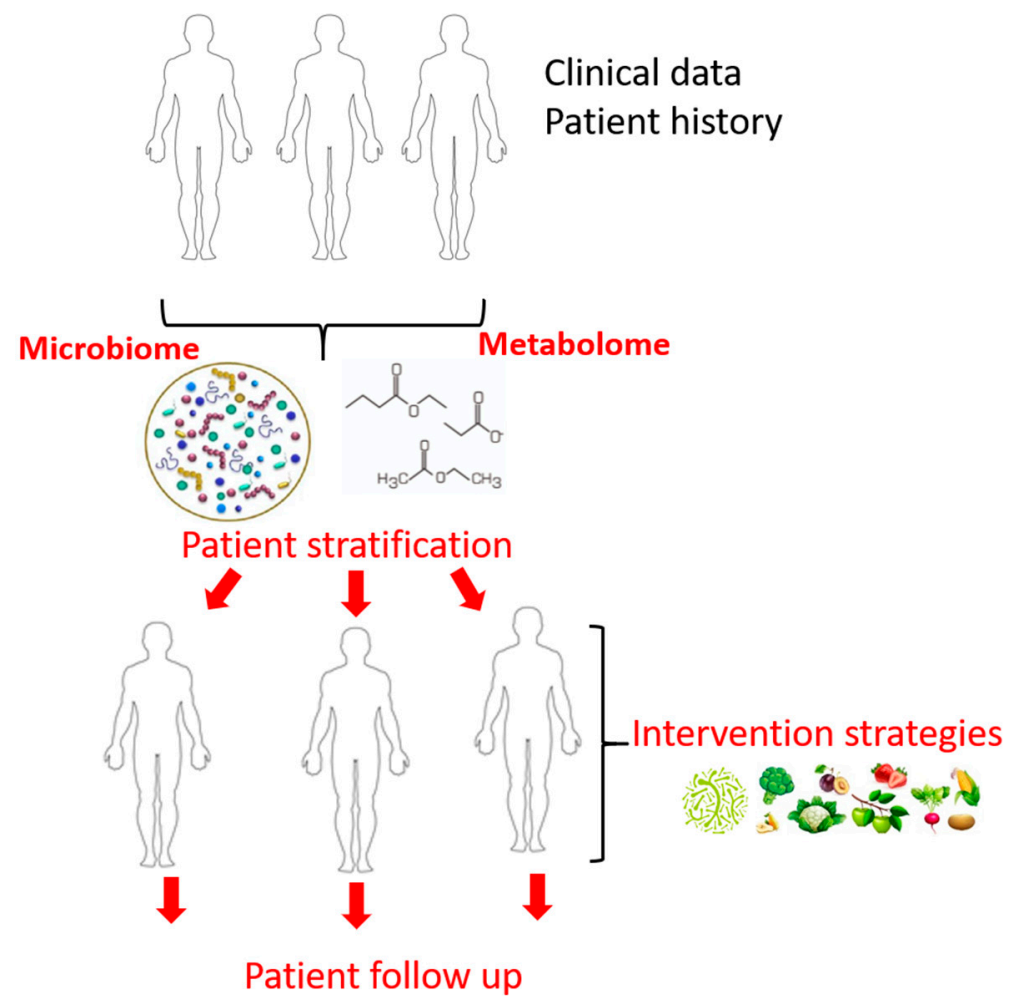

Figure 2. Proposed personalized therapeutic approaches in T1DM.

\section{Conclusions}

Clinical management of diabetes involves strategies targeting modifiable risk factors that aim to reduce the development of specific complications. As lack of endogenous insulin is the key element in pathogenesis of T1DM, exogenous insulin therapy is of outmost importance. However, high variability occurs in response to classical therapeutic interventions. Hence, clinical approaches in diabetes as well as in other ailments need to switch from "one size fits all" to personalized medicine. A better understanding of the unique characteristics of each patient will explain the underlying causes for differential pharmacological responses and will improve treatment options. Knowledge gained from microbiome research is a promising step in T1DM field. Even though the studies presented within this review offer a picture regarding the microbiome thriving in the T1DM gut, they generally targeted white populations with early-onset disease so there are still many questions awaiting.

Nevertheless, by targeting the microbiota, we will be able to more precisely characterize and treat diabetes. Probiotics, prebiotics, dietary factors and microbiota transplantation can all modulate early host-microbiota interactions by enabling beneficial microbes with protective potential for individuals with T1DM or at high risk of developing T1DM. Nevertheless, this progress will only be possible if we focus our interest on developing numerous longitudinal, multicenter, interventional and double-blind randomized clinical trials to confirm their efficacy and safety of these therapeutic approaches.

Moreover, the advent of omics profiling technologies has a huge impact in identifying unique biological signatures to allow personalized treatments in diabetes. Importantly, omic technologies need be scaled up and made available to many individuals because currently, many of these tools used in precision medicine are expensive and not accessible in many parts of the world. Future research studies need to better characterize healthassociated taxa in correlation with their functional features (i.e., SCFAs production) and their delivery to a recipient host. Importantly, the patient's individual microbial profiles should be characterized before employing personalized therapeutic approaches. 
Author Contributions: Conceptualization, G.G.P. and O.S.; writing-original draft preparation, G.G.P., O.S., L.G.M., M.-C.C., B.I.; writing-review and editing, N.C., O.G. All authors have read and agreed to the published version of the manuscript.

Funding: This research was funded by UEFISCDI, project ID PN-III-P1-1.1-PD-2019-0499, grant number 224/2021.

Institutional Review Board Statement: Not applicable.

Informed Consent Statement: Not applicable.

Data Availability Statement: Not applicable.

Conflicts of Interest: The authors declare no conflict of interest.

\section{References}

1. Penders, J.; Thijs, C.; Vink, C.; Stelma, F.F.; Snijders, B.; Kummeling, I.; Van den Brandt, P.A.; Stobberingh, E.E. Factors influencing the composition of the intestinal microbiota in early infancy. Pediatrics 2006, 118, 511-521. [CrossRef]

2. Lazar, V.; Ditu, L.-M.; Pircalabioru, G.G.; Picu, A.; Petcu, L.; Cucu, N.; Chifiriuc, M.C. Gut microbiota, host organism, and diet trialogue in diabetes and obesity. Front. Nutr. 2019, 6, 21. [CrossRef]

3. Vatanen, T.; Kostic, A.D.; D'Hennezel, E.; Siljander, H.; Franzosa, E.A.; Yassour, M.; Kolde, R.; Vlamakis, H.; Arthur, T.D.; Hämäläinen, A.-M.; et al. Variation in microbiome lps immunogenicity contributes to autoimmunity in humans. Cell 2016, 165, 842-853. [CrossRef] [PubMed]

4. Patterson, C.; Guariguata, L.; Dahlquist, G.; Soltész, G.; Ogle, G.; Silink, M. Diabetes in the young-A global view and worldwide estimates of numbers of children with type 1 diabetes. Diabetes Res. Clin. Pract. 2014, 103, 161-175. [CrossRef] [PubMed]

5. Gavin, P.G.; Hamilton-Williams, E.E. The gut microbiota in type 1 diabetes. Curr. Opin. Endocrinol. Diabetes Obes. 2019, 26, 207-212. [CrossRef] [PubMed]

6. American-Diabetes-Association. Standards of medical care in diabetes. Diabetes Care 2020, 43, S1-S207.

7. Department of Health and Human Services: Centers for Disease Control and Prevention. Ndfs_2011. In National Diabetes Fact Sheet: National Estimates General Information Diabetes Prediabetes USA; Centers for Disease Control and Prevention: Atlanta, GA, USA, 2011.

8. Imkampe, A.-K.; Gulliford, M. Trends in type 1 diabetes incidence in the UK in 0- to 14-year-olds and in 15- to 34-year-olds, 1991-2008. Diabet. Med. 2011, 28, 811-814. [CrossRef] [PubMed]

9. Diaz-Valencia, P.A.; Bougnères, P.; Valleron, A.-J. Global epidemiology of type 1 diabetes in young adults and adults: A systematic review. BMC Public Health 2015, 15, 1-15. [CrossRef]

10. Mayer-Davis, E.J.; Kahkoska, A.R.; Jefferies, C.; Dabelea, D.; Balde, N.; Gong, C.X.; Aschner, P.; Craig, M.E. ISPAD clinical practice consensus guidelines 2018: Definition, epidemiology, and classification of diabetes in children and adolescents. Pediatr. Diabetes 2018, 19, 7-19. [CrossRef]

11. Katsarou, A.; Gudbjörnsdottir, S.; Rawshani, A.; Dabelea, D.; Bonifacio, E.; Anderson, B.J.; Jacobsen, L.M.; Schatz, D.A.; Lernmark, A. Type 1 diabetes mellitus. Nat. Rev. Dis. Primers 2017, 3, nrdp201716. [CrossRef]

12. Tuomilehto, J. The emerging global epidemic of type 1 diabetes. Curr. Diabetes Rep. 2013, 13, 795-804. [CrossRef]

13. Knip, M. Pathogenesis of type 1 diabetes: Implications for incidence trends. Horm. Res. Paediatr. 2011, 76, 57-64. [CrossRef]

14. Hooper, L.V.; Littman, D.R.; MacPherson, A.J. Interactions between the microbiota and the immune system. Science 2012, 336, 1268-1273. [CrossRef]

15. Umoh, F.I.; Kato, I.; Ren, J.; Wachowiak, P.L.; Ruffin, M.T.; Turgeon, D.K.; Sen, A.; Brenner, D.E.; Djuric, Z. Markers of systemic exposures to products of intestinal bacteria in a dietary intervention study. Eur. J. Nutr. 2016, 55, 793-798. [CrossRef] [PubMed]

16. Quercia, S.; Candela, M.; Giuliani, C.; Turroni, S.; Luiselli, D.; Rampelli, S.; Brigidi, P.; Franceschi, C.; Bacalini, M.G.; Garagnani, P.; et al. From lifetime to evolution: Timescales of human gut microbiota adaptation. Front. Microbiol. 2014, 5, 587. [CrossRef] [PubMed]

17. Siljander, H.; Honkanen, J.; Knip, M. Microbiome and type 1 diabetes. EBioMedicine 2019, 46, 512-521. [CrossRef] [PubMed]

18. Candon, S.; Perez-Arroyo, A.; Marquet, C.; Valette, F.; Foray, A.-P.; Pelletier, B.; Milani, C.; Ventura, M.; Bach, J.-F.; Chatenoud, L. Antibiotics in early life alter the gut microbiome and increase disease incidence in a spontaneous mouse model of autoimmune insulin-dependent diabetes. PLOS ONE 2015, 10, e0125448. [CrossRef]

19. Hu, Y.; Jin, P.; Peng, J.; Zhang, X.; Wong, F.S.; Wen, L. Different immunological responses to early-life antibiotic exposure affecting autoimmune diabetes development in NOD mice. J. Autoimmun. 2016, 72, 47-56. [CrossRef]

20. Hansen, C.H.F.; Krych, L.; Nielsen, D.S.; Vogensen, F.K.; Hansen, L.H.; Sørensen, S.J.; Buschard, K.; Hansen, A.K. Early life treatment with vancomycin propagates Akkermansia muciniphila and reduces diabetes incidence in the NOD mouse. Diabetologia 2012, 55, 2285-2294. [CrossRef]

21. Hu, Y.; Peng, J.; Tai, N.; Hu, C.; Zhang, X.; Wong, F.S.; Wen, L. Maternal antibiotic treatment protects offspring from diabetes development in nonobese diabetic mice by generation of tolerogenic APCs. J. Immunol. 2015, 195, 4176-4184. [CrossRef] 
22. Livanos, A.E.; Greiner, T.U.; Vangay, P.; Pathmasiri, W.; Stewart, D.; McRitchie, S.; Li, H.; Chung, J.; Sohn, J.; Kim, S.; et al. Antibiotic-mediated gut microbiome perturbation accelerates development of type 1 diabetes in mice. Nat. Microbiol. 2016, 1, 1-13. [CrossRef]

23. Alkanani, A.K.; Hara, N.; Lien, E.; Ir, D.; Kotter, C.V.; Robertson, C.E.; Wagner, B.D.; Frank, D.N.; Zipris, D. Induction of Diabetes in the RIP-B7.1 Mouse Model Is Critically Dependent on TLR3 and MyD88 Pathways and Is Associated With Alterations in the Intestinal Microbiome. Diabetes 2013, 63, 619-631. [CrossRef]

24. Gülden, E.; Ihira, M.; Ohashi, A.; Reinbeck, A.L.; Freudenberg, M.A.; Kolb, H.; Burkart, V. Toll-like receptor 4 deficiency accelerates the development of insulin-deficient diabetes in non-obese diabetic mice. PLoS ONE 2013, 8, e75385. [CrossRef]

25. Zhang, Y.; Lee, A.S.; Shameli, A.; Geng, X.; Finegood, D.; Santamaria, P.; Dutz, J.P. TLR9 blockade inhibits activation of diabetogenic CD8+ T cells and delays autoimmune diabetes. J. Immunol. 2010, 184, 5645-5653. [CrossRef]

26. Wen, L.; Ley, R.E.; Volchkov, P.Y.; Stranges, P.B.; Avanesyan, L.; Stonebraker, A.C.; Hu, C.; Wong, F.S.; Szot, G.L.; Bluestone, J.A.; et al. Innate immunity and intestinal microbiota in the development of type 1 diabetes. Nat. Cell Biol. 2008, 455, 1109-1113. [CrossRef] [PubMed]

27. Brown, C.T.; Davis-Richardson, A.G.; Giongo, A.; Gano, K.A.; Crabb, D.B.; Mukherjee, N.; Casella, G.; Drew, J.C.; Ilonen, J.; Knip, M.; et al. Gut Microbiome Metagenomics Analysis Suggests a Functional Model for the Development of Autoimmunity for type 1 diabetes. PLoS ONE 2011, 6, e25792. [CrossRef] [PubMed]

28. De Goffau, M.C.; Luopajärvi, K.; Knip, M.; Ilonen, J.; Ruohtula, T.; Härkönen, T.; Orivuori, L.; Hakala, S.; Welling, G.W.; Harmsen, H.J.; et al. Fecal microbiota composition differs between children with $\beta$-cell autoimmunity and those without. Diabetes 2013, 62, 1238-1244. [CrossRef] [PubMed]

29. De Goffau, M.C.; Fuentes, S.; Bogert, B.V.D.; Honkanen, H.; De Vos, W.M.; Welling, G.W.; Hyöty, H.; Harmsen, H.J.M. Aberrant gut microbiota composition at the onset of type 1 diabetes in young children. Diabetologia 2014, 57, 1569-1577. [CrossRef]

30. De Groot, P.F.; Belzer, C.; Aydin, Ö.; Levin, E.; Levels, J.H.; Aalvink, S.; Boot, F.; Holleman, F.; Van Raalte, D.H.; Scheithauer, T.P.; et al. Distinct fecal and oral microbiota composition in human type 1 diabetes, an observational study. PLoS ONE 2017, 12, e0188475. [CrossRef]

31. Paparo, L.; Di Costanzo, M.; Di Scala, C.; Cosenza, L.; Leone, L.; Nocerino, R.; Canani, R.B. The influence of early life nutrition on epigenetic regulatory mechanisms of the immune system. Nutrients 2014, 6, 4706-4719. [CrossRef]

32. Arpaia, N.; Campbell, C.; Fan, X.; Dikiy, S.; Van Der Veeken, J.; DeRoos, P.; Liu, H.; Cross, J.R.; Pfeffer, K.; Coffer, P.J.; et al. Metabolites produced by commensal bacteria promote peripheral regulatory T-cell generation. Nature 2013, 504, $451-455$. [CrossRef] [PubMed]

33. Furusawa, Y.; Obata, Y.; Fukuda, S.; Endo, T.A.; Nakato, G.; Takahashi, D.; Nakanishi, Y.; Uetake, C.; Kato, K.; Kato, T.; et al. Commensal microbe-derived butyrate induces the differentiation of colonic regulatory T cells. Nature 2013, 504, 446-450. [CrossRef] [PubMed]

34. Morrison, D.J.; Preston, T. Formation of short chain fatty acids by the gut microbiota and their impact on human metabolism. Gut Microbes 2016, 7, 189-200. [CrossRef]

35. Maffeis, C.; Martina, A.; Corradi, M.; Quarella, S.; Nori, N.; Torriani, S.; Plebani, M.; Contreas, G.; Felis, G.E. Association between intestinal permeability and faecal microbiota composition in Italian children with beta cell autoimmunity at risk for type 1 diabetes. Diabetes Metab. Res. Rev. 2016, 32, 700-709. [CrossRef]

36. Kostic, A.D.; Gevers, D.; Siljander, H.; Vatanen, T.; Hyötyläinen, T.; Hämäläinen, A.-M.; Peet, A.; Tillmann, V.; Pöhö, P.; Mattila, I.; et al. The dynamics of the human infant gut microbiome in development and in progression toward type 1 diabetes. Cell Host Microbe 2015, 17, 260-273. [CrossRef]

37. Vatanen, T.; Franzosa, E.A.; Schwager, R.; Tripathi, S.; Arthur, T.D.; Vehik, K.; Lernmark, Å.; Hagopian, W.A.; Rewers, M.J.; She, J.-X.; et al. The human gut microbiome in early-onset type 1 diabetes from the TEDDY study. Nat. Cell Biol. 2018, 562, 589-594. [CrossRef]

38. Hagopian, W.A.; Erlich, H.; Lernmark, Å.; Rewers, M.; Ziegler, A.G.; Simell, O.; Akolkar, B.; Vogt, R.; Blair, A.; Ilonen, J.; et al. The environmental determinants of diabetes in the young (TEDDY): Genetic criteria and international diabetes risk screening of 421,000 infants. Pediatr. Diabetes 2011, 12, 733-743. [CrossRef]

39. Bäckhed, F.; Ley, R.E.; Sonnenburg, J.L.; Peterson, D.A.; Gordon, J.I. Host-bacterial mutualism in the human intestine. Science 2005, 307, 1915-1920. [CrossRef] [PubMed]

40. Durazzo, M.; Ferro, A.; Gruden, G. Gastrointestinal microbiota and type 1 diabetes mellitus: The state of art. J. Clin. Med. 2019, 8 , 1843. [CrossRef] [PubMed]

41. Murri, M.; Leiva, I.; Gomez-Zumaquero, J.M.; Tinahones, F.J.; Cardona, F.; Soriguer, F.; Queipo-Ortuño, M.I. Gut microbiota in children with type 1 diabetes differs from that in healthy children: A case-control study. BMC Med. 2013, 11, 46. [CrossRef]

42. Mejía-León, M.E.; Petrosino, J.F.; Ajami, N.J.; Domínguez-Bello, M.G.; De La Barca, A.M.C. Fecal microbiota imbalance in Mexican children with type 1 diabetes. Sci. Rep. 2015, 4, 3814. [CrossRef]

43. Leiva-Gea, I.; Sánchez-Alcoholado, L.; Martín-Tejedor, B.; Castellano-Castillo, D.; Moreno-Indias, I.; Urda-Cardona, A.; Tinahones, F.J.; Fernández-García, J.C.; Queipo-Ortuño, M.I. Gut microbiota differs in composition and functionality between children with type 1 diabetes and MODY2 and healthy control subjects: A case-control study. Diabetes Care 2018, 41, 2385-2395. [CrossRef]

44. Pinto, E.; Anselmo, M.; Calha, M.; Bottrill, A.; Duarte, I.; Andrew, P.W.; Faleiro, M.L. The intestinal proteome of diabetic and control children is enriched with different microbial and host proteins. Microbiology 2017, 163, 161-174. [CrossRef] 
45. Paassen, N.B.-V.; Vincent, A.; Puiman, P.J.; Van Der Sluis, M.; Bouma, J.; Boehm, G.; Van Goudoever, J.B.; Van Seuningen, I.; Renes, I.B. The regulation of intestinal mucin MUC2 expression by short-chain fatty acids: Implications for epithelial protection. Biochem. J. 2009, 420, 211-219. [CrossRef]

46. Flint, H.J.; Scott, K.P.; Duncan, S.H.; Louis, P.; Forano, E. Microbial degradation of complex carbohydrates in the gut. Gut Microbes 2012, 3, 289-306. [CrossRef] [PubMed]

47. Hague, A.; Butt, A.J.; Paraskeva, C. The role of butyrate in human colonic epithelial cells: An energy source or inducer of differentiation and apoptosis? Proc. Nutr. Soc. 1996, 55, 937-943. [CrossRef] [PubMed]

48. Peng, L.; Li, Z.-R.; Green, R.S.; Holzman, I.R.; Lin, J. Butyrate enhances the intestinal barrier by facilitating tight junction assembly via activation of AMP-activated protein kinase in Caco-2 cell monolayers. J. Nutr. 2009, 139, 1619-1625. [CrossRef] [PubMed]

49. Rosenfeldt, V.; Benfeldt, E.; Valerius, N.H.; Pærregaard, A.; Michaelsen, K.F. Effect of probiotics on gastrointestinal symptoms and small intestinal permeability in children with atopic dermatitis. J. Pediatr. 2004, 145, 612-616. [CrossRef]

50. Valladares, R.; Sankar, D.; Li, N.; Williams, E.; Lai, K.-K.; Abdelgeliel, A.S.; Gonzalez, C.F.; Wasserfall, C.H.; Larkin, J.; Schatz, D.; et al. Lactobacillus johnsonii N6.2 Mitigates the development of type 1 diabetes in BB-DP rats. PLoS ONE 2010, 5, e10507. [CrossRef]

51. Karczewski, J.; Troost, F.J.; Konings, I.; Dekker, J.; Kleerebezem, M.; Brummer, R.-J.M.; Wells, J.M. Regulation of human epithelial tight junction proteins by lactobacillus plantarum in vivo and protective effects on the epithelial barrier. Am. J. Physiol. Liver Physiol. 2010, 298, G851-G859. [CrossRef]

52. Stratiki, Z.; Costalos, C.; Sevastiadou, S.; Kastanidou, O.; Skouroliakou, M.; Giakoumatou, A.; Petrohilou, V. The effect of a bifidobacter supplemented bovine milk on intestinal permeability of preterm infants. Early Hum. Dev. 2007, 83, 575-579. [CrossRef] [PubMed]

53. Duncan, S.H.; Louis, P.; Flint, H.J. Lactate-utilizing bacteria, isolated from human feces, that produce butyrate as a major fermentation product. Appl. Environ. Microbiol. 2004, 70, 5810-5817. [CrossRef]

54. Zhou, H.; Sun, L.; Zhang, S.; Zhao, X.; Gang, X.; Wang, G. Evaluating the causal role of gut microbiota in type 1 diabetes and its possible pathogenic mechanisms. Front. Endocrinol. 2020, 11, 11. [CrossRef]

55. Giongo, A.A.; Gano, K.; Crabb, D.B.; Mukherjee, N.; Novelo, L.L.; Casella, G.; Drew, J.C.; Ilonen, J.; Knip, M.; Hyöty, H.; et al. Toward defining the autoimmune microbiome for type 1 diabetes. ISME J. 2010, 5, 82-91. [CrossRef]

56. Uusitalo, U.; Liu, X.; Yang, J.; Aronsson, C.A.; Hummel, S.; Butterworth, M.; Lernmark, Å.; Rewers, M.; Hagopian, W.; She, J.-X.; et al. Association of early exposure of probiotics and islet autoimmunity in the TEDDY study. JAMA Pediatr. 2016, 170, 20-28. [CrossRef]

57. Ho, J.; Nicolucci, A.C.; Virtanen, H.; Schick, A.; Meddings, J.; Reimer, R.A.; Huang, C. Effect of prebiotic on microbiota, intestinal permeability and glycemic control in children with type 1 diabetes. J. Clin. Endocrinol. Metab. 2019, 104, 4427-4440. [CrossRef]

58. Sonnenburg, J.L.; Bäckhed, F. Diet-microbiota interactions as moderators of human metabolism. Nat. Cell Biol. 2016, 535, 56-64. [CrossRef] [PubMed]

59. Chen, J.; Wright, K.; Davis, J.M.; Jeraldo, P.; Marietta, E.V.; Murray, J.; Nelson, H.; Matteson, E.L.; Taneja, V. An expansion of rare lineage intestinal microbes characterizes rheumatoid arthritis. Genome Med. 2016, 8, 1-14. [CrossRef]

60. Jangi, S.; Gandhi, R.; Cox, L.M.; Li, N.; Von Glehn, F.; Yan, R.; Patel, B.; Mazzola, M.A.; Liu, S.; Glanz, B.L.; et al. Alterations of the human gut microbiome in multiple sclerosis. Nat. Commun. 2016, 7, 12015. [CrossRef] [PubMed]

61. Virtanen, S.M.; Nevalainen, J.; Kronberg-Kippilä, C.; Ahonen, S.; Tapanainen, H.; Uusitalo, L.; Takkinen, H.-M.; Niinistö, S.; Ovaskainen, M.-L.; Kenward, M.G.; et al. Food consumption and advanced $\beta$ cell autoimmunity in young children with HLA-conferred susceptibility to type 1 diabetes: A nested case-control design. Am. J. Clin. Nutr. 2012, 95, 471-478. [CrossRef] [PubMed]

62. Davis-Richardson, A.G.; Triplett, E.W. A model for the role of gut bacteria in the development of autoimmunity for type 1 diabetes. Diabetologia 2015, 58, 1386-1393. [CrossRef] [PubMed]

63. Lamb, M.M.; Miller, M.; Seifert, J.A.; Frederiksen, B.; Kroehl, M.; Rewers, M.; Norris, J.M. The effect of childhood cow's milk intake and HLA-DR genotype on risk of islet autoimmunity and type 1 diabetes: The Diabetes autoimmunity study in the young. Pediatr. Diabetes 2015, 16, 31-38. [CrossRef] [PubMed]

64. Kaprio, J.; Tuomilehto, J.; Koskenvuo, M.; Romanov, K.; Reunanen, A.; Eriksson, J.; Stengård, J.; Kesäniemi, Y.A. Concordance for type 1 (insulin-dependent) and type 2 (non-insulin-dependent) diabetes mellitus in a population-based cohort of twins in Finland. Diabetologia 1992, 35, 1060-1067. [CrossRef]

65. Vangay, P.; Johnson, A.J.; Ward, T.L.; Al-Ghalith, G.A.; Shields-Cutler, R.R.; Hillmann, B.M.; Lucas, S.K.; Beura, L.K.; Thompson, E.A.; Till, L.M.; et al. US immigration westernizes the human gut microbiome. Cell 2018, 175, 962-972. [CrossRef]

66. Singh, R.K.; Chang, H.-W.; Yan, D.; Lee, K.M.; Ucmak, D.; Wong, K.; Abrouk, M.; Farahnik, B.; Nakamura, M.; Zhu, T.H.; et al. Influence of diet on the gut microbiome and implications for human health. J. Transl. Med. 2017, 15, 1-17. [CrossRef] [PubMed]

67. Suez, J.; Korem, T.; Zeevi, D.; Zilberman-Schapira, G.; Thaiss, C.A.; Maza, O.; Israeli, D.; Zmora, N.; Gilad, S.; Weinberger, A.; et al. Artificial sweeteners induce glucose intolerance by altering the gut microbiota. Nat. Cell Biol. 2014, 514, 181-186. [CrossRef]

68. Scott, F.W.; Cloutier, H.E.; Kleemann, R.; Wöerz-Pagenstert, U.; Rowsell, P.; Modler, H.W.; Kolb, H. Potential mechanisms by which certain foods promote or inhibit the development of spontaneous diabetes in BB rats: Dose, timing, early effect on islet area, and switch in infiltrate from Th1 to Th2 cells. Diabetes 1997, 46, 589-598. [CrossRef] 
69. Verge, C.F.; Howard, N.J.; Irwig, L.; Simpson, J.M.; Mackerras, D.; Silink, M.; McNeely, M.J.; Boyko, E.J.; Ahroni, J.H.; Stensel, V.L.; et al. Environmental factors in childhood IDDM: A population-based, case-control study. Diabetes Care 1994, 17, 1381-1389. [CrossRef] [PubMed]

70. Lammers, K.M.; Lu, R.; Brownley, J.; Lu, B.; Gerard, C.; Thomas, K.; Rallabhandi, P.; Shea-Donohue, T.; Tamiz, A.; Alkan, S.; et al. Gliadin induces an increase in intestinal permeability and zonulin release by binding to the chemokine receptor CXCR3. Gastroenterology 2008, 135, 194-204. [CrossRef] [PubMed]

71. Haupt-Jorgensen, M.; Holm, L.J.; Josefsen, K.; Buschard, K. Possible prevention of diabetes with a gluten-free diet. Nutrients 2018, 10, 1746. [CrossRef] [PubMed]

72. Dedrick, S.; Sundaresh, B.; Huang, Q.; Brady, C.; Yoo, T.; Cronin, C.; Rudnicki, C.; Flood, M.; Momeni, B.; Ludvigsson, J.; et al. The role of gut microbiota and environmental factors in type 1 diabetes pathogenesis. Front. Endocrinol. 2020, 11, 1-20. [CrossRef]

73. Hänninen, A.; Toivonen, R.; Pöysti, S.; Belzer, C.; Plovier, H.; Ouwerkerk, J.P.; Emani, R.; Cani, P.D.; De Vos, W.M. Akkermansia muciniphila induces gut microbiota remodelling and controls islet autoimmunity in NOD mice. Gut 2017, 67, 1445-1453. [CrossRef]

74. Ziegler, A.-G.; Schmid, S.; Huber, D.; Hummel, M.; Bonifacio, E. Early infant feeding and risk of developing type 1 diabetesAssociated autoantibodies. JAMA 2003, 290, 1721-1728. [CrossRef]

75. Norris, J.M.; Barriga, K.; Klingensmith, G.; Hoffman, M.; Eisenbarth, G.S.; Erlich, H.A.; Rewers, M. Timing of initial cereal exposure in infancy and risk of islet autoimmunity. JAMA 2003, 290, 1713-1720. [CrossRef] [PubMed]

76. Dieterich, W.; Esslinger, B.; Schuppan, D. Pathomechanisms in celiac disease. Int. Arch. Allergy Immunol. 2003, 132, 98-108. [CrossRef]

77. Saadah, O.I.; Zacharin, M.; O'Callaghan, A.; Oliver, M.R.; Catto-Smith, A.G. Effect of gluten-free diet and adherence on growth and diabetic control in diabetics with coeliac disease. Arch. Dis. Child. 2004, 89, 871-876. [CrossRef] [PubMed]

78. Hansen, A.K.; Ling, F.; Kaas, A.; Funda, D.P.; Farlov, H.; Buschard, K. Diabetes preventive gluten-free diet decreases the number of caecal bacteria in non-obese diabetic mice. Diabetes Metab. Res. Rev. 2006, 22, 220-225. [CrossRef] [PubMed]

79. Rami, B.; Sumnik, Z.; Schober, E.; Waldhör, T.; Battelino, T.; Bratanic, N.; Kürti, K.; Lebl, J.; Limbert, C.; Madacsy, L.; et al. Screening detected celiac disease in children with type 1 diabetes mellitus: Effect on the clinical course (A case control study). $J$. Pediatr. Gastroenterol. Nutr. 2005, 41, 317-321. [CrossRef] [PubMed]

80. Westman, E.; Ambler, G.; Royle, M.; Peat, J.; Chan, A. Children with coeliac disease and insulin dependent diabetes mellitusGrowth, diabetes control and dietary intake. J. Pediatr. Endocrinol. Metab. 1999, 12, 433-442. [CrossRef]

81. Savilahti, E.; Saukkonen, T.T.; Virtala, E.T.; Tuomilehto, J.; Åkerblom, H.K. The childhood diabetes in Finland study group increased levels of cow's milk and -lactoglobulin antibodies in young children with newly diagnosed IDDM. Diabetes Care 1993, 16, 984-989. [CrossRef]

82. Robertson, L.; Harrild, K. Maternal and neonatal risk factors for childhood type 1 diabetes: A matched case-control study. BMC Public Health 2010, 10, 281. [CrossRef]

83. Savilahti, E.; Saarinen, K.M. Early infant feeding and type 1 diabetes. Eur. J. Nutr. 2009, 48, 243-249. [CrossRef]

84. Vaarala, O.; Ilonen, J.; Ruohtula, T.; Pesola, J.; Virtanen, S.M.; Härkönen, T.; Koski, M.; Kallioinen, H.; Tossavainen, O.; Poussa, T.; et al. Removal of bovine insulin from cow's milk formula and early initiation of beta-cell autoimmunity in the FINDIA pilot study. Arch. Pediatr. Adolesc. Med. 2012, 166, 608-614. [CrossRef]

85. Pannaraj, P.S.; Li, F.; Cerini, C.; Bender, J.M.; Yang, S.; Rollie, A.; Adisetiyo, H.; Zabih, S.; Lincez, P.J.; Bittinger, K.; et al. Association between breast milk bacterial communities and establishment and development of the infant gut microbiome. JAMA Pediatr. 2017, 171, 647-654. [CrossRef]

86. Mueller, N.T.; Bakacs, E.; Combellick, J.; Grigoryan, Z.; Dominguez-Bello, M.G. The infant microbiome development: Mom matters. Trends Mol. Med. 2015, 21, 109-117. [CrossRef]

87. Mueller, D.B.; Koczwara, K.; Mueller, A.S.; Pallauf, J.; Ziegler, A.-G.; Bonifacio, E. Influence of early nutritional components on the development of murine autoimmune diabetes. Ann. Nutr. Metab. 2009, 54, 208-217. [CrossRef] [PubMed]

88. Alves, J.G.B.; Figueiroa, J.N.; Meneses, J.; Alves, G.V. Breastfeeding protects against type 1 diabetes mellitus: A case-sibling study. Breastfeed. Med. 2012, 7, 25-28. [CrossRef] [PubMed]

89. Lund-Blix, N.A.; Stene, L.C.; Rasmussen, T.; Torjesen, P.A.; Andersen, L.F.; Rønningen, K.S. Infant feeding in relation to islet autoimmunity and type 1 diabetes in genetically susceptible children: The MIDIA study. Diabetes Care 2014, 38, $257-263$. [CrossRef] [PubMed]

90. Holmberg, H.; Wahlberg, J.; Vaarala, O.; Ludvigsson, J. For the ABIS study group short duration of breast-feeding as a risk-factor for $\beta$-cell autoantibodies in 5-year-old children from the general population. Br. J. Nutr. 2007, 97, 111-116. [CrossRef]

91. Sadauskaitè-Kuehne, V.; Ludvigsson, J.; Padaiga, Z.; Jašinskienè, E.; Samuelsson, U. Longer breastfeeding is an independent protective factor against development of type 1 diabetes mellitus in childhood. Diabetes Metab. Res. Rev. 2004, 20, 150-157. [CrossRef]

92. Mishra, S.P.; Wang, S.; Nagpal, R.; Miller, B.; Singh, R.; Taraphder, S.; Yadav, H. Probiotics and prebiotics for the amelioration of type 1 diabetes: Present and future perspectives. Microorganism 2019, 7, 67. [CrossRef] [PubMed]

93. Udayappan, S.D.; Hartstra, A.V.; Dallinga-Thie, G.M.; Nieuwdorp, M. Intestinal microbiota and faecal transplantation as treatment modality for insulin resistance and type 2 diabetes mellitus. Clin. Exp. Immunol. 2014, 177, 24-29. [CrossRef] 
94. Jamshidi, P.; Hasanzadeh, S.; Tahvildari, A.; Farsi, Y.; Arbabi, M.; Mota, J.F.; Sechi, L.A.; Nasiri, M.J. Is there any association between gut microbiota and type 1 diabetes? A systematic review. Gut Pathog. 2019, 11, 1-10. [CrossRef]

95. Abdellatif, A.M.; Sarvetnick, N.E. Current understanding of the role of gut dysbiosis in type 1 diabetes. J. Diabetes 2019, 11, 632-644. [CrossRef] [PubMed]

96. Zheng, P.; Li, Z.; Zhou, Z. Gut microbiome in type 1 diabetes: A comprehensive review. Diabetes Metab. Res. Rev. 2018, 34 , e3043. [CrossRef] [PubMed]

97. Han, H.; Li, Y.; Fang, J.; Liu, G.; Yin, J.; Li, T.; Yin, Y. Gut microbiota and type 1 diabetes. Int. J. Mol. Sci. 2018, 19, 995. [CrossRef]

98. Abbasi, B.; Ghiasvand, R. Kidney function improvement by soy milk containing lactobacillus plantarum A7 in type 2 diabetic patients with nephropathy: A double-blinded randomized controlled trial. Iran. J. Kidney Dis. 2017, 11, 36-43. [PubMed]

99. Firouzi, S.; Mohd-Yusof, B.-N.; Majid, H.-A.; Ismail, A.; Kamaruddin, N.-A. Effect of microbial cell preparation on renal profile and liver function among type 2 diabetics: A randomized controlled trial. BMC Complementary Altern. Med. 2015, 15, 433. [CrossRef]

100. Mafi, A.; Namazi, G.; Soleimani, A.; Bahmani, F.; Aghadavod, E.; Asemi, Z. Metabolic and genetic response to probiotics supplementation in patients with diabetic nephropathy: A randomized, double-blind, placebo-controlled trial. Food Funct. 2018, 9, 4763-4770. [CrossRef]

101. Soleimani, A.; Mojarrad, M.Z.; Bahmani, F.; Taghizadeh, M.; Ramezani, M.; Tajabadi-Ebrahimi, M.; Jafari, P.; Esmaillzadeh, A.; Asemi, Z. Probiotic supplementation in diabetic hemodialysis patients has beneficial metabolic effects. Kidney Int. 2017, 91, 435-442. [CrossRef]

102. Mazruei Arani, N.; Emam-Djomeh, Z.; Tavakolipour, H.; Sharafati-Chaleshtori, R.; Soleimani, A.; Asemi, Z. The effects of pro-biotic honey consumption on metabolic status in patients with diabetic nephropathy: A randomized, double-blind, controlled trial. Probiotics Antimicrob Proteins 2019, 11, 1195-1201. [CrossRef]

103. Miraghajani, M.; Zaghian, N.; Mirlohi, M.; Feizi, A.; Ghiasvand, R. The impact of probiotic soy milk consumption on oxidative stress among type 2 diabetic kidney disease patients: A randomized controlled clinical trial. J. Ren. Nutr. 2017, 27, 317-324. [CrossRef]

104. Homme, R.P.; George, A.K.; Stanisic, D.N.; Malonee, C.; Molnar, J. Effects of probiotic on the development of diabetic retinopathy. ARVO Annu. Meet. 2020, 61, 4961.

105. Raygan, F.; Rezavandi, Z.; Bahmani, F.; Ostadmohammadi, V.; Mansournia, M.A.; Tajabadi-Ebrahimi, M.; Borzabadi, S.; Asemi, Z. The effects of probiotic supplementation on metabolic status in type 2 diabetic patients with coronary heart disease. Diabetol. Metab. Syndr. 2018, 10, 1-7. [CrossRef]

106. Li, Q.; Xu, K.; Du, T.; Zhu, P.; Verma, A. Recombinant probiotics expressing angiotensin-(1-7) improves glucose metabolism and diabetes-induced renal and retinal injury. Diabetes 2018, 67, 33. [CrossRef]

107. Ho, J.; Reimer, R.A.; Doulla, M.; Huang, C. Effect of prebiotic intake on gut microbiota, intestinal permeability and glycemic control in children with type 1 diabetes: Study protocol for a randomized controlled trial. Trials 2016, 17, 1-8. [CrossRef] [PubMed]

108. Cani, P.D.; Possemiers, S.; Van De Wiele, T.; Guiot, Y.; Everard, A.; Rottier, O.; Geurts, L.; Naslain, D.; Neyrinck, A.; Lambert, D.M.; et al. Changes in gut microbiota control inflammation in obese mice through a mechanism involving GLP-2-driven improvement of gut permeability. Gut 2009, 58, 1091-1103. [CrossRef] [PubMed]

109. De Groot, P.; Nikolic, T.; Pellegrini, S.; Sordi, V.; Imangaliyev, S.; Rampanelli, E.; Hanssen, N.; Attaye, I.; Bakker, G.; Duinkerken, G.; et al. Faecal microbiota transplantation halts progression of human new-onset type 1 diabetes in a randomised controlled trial. Gut 2021, 70, 92-105. [CrossRef] [PubMed]

110. Ge, S.; Wang, Y.; Song, M.; Li, X.; Yu, X.; Wang, H.; Wang, J.; Zeng, Q.; Wang, W. Type 2 diabetes mellitus: Integrative analysis of multiomics data for biomarker discovery. OMICS J. Integr. Biol. 2018, 22, 514-523. [CrossRef] [PubMed]

111. Collares, C.V.A.; Evangelista, A.F.; Xavier, D.J.; Rassi, D.M.; Arns, T.; Foss-Freitas, M.C.; Foss, M.C.; Puthier, D.; Sakamoto-Hojo, E.T.; Passos, G.A.; et al. Identifying common and specific microRNAs expressed in peripheral blood mononuclear cell of type 1, type 2, and gestational diabetes mellitus patients. BMC Res. Notes 2013, 6, 491. [CrossRef] [PubMed]

112. Erener, S.; Marwaha, A.; Tan, R.; Panagiotopoulos, C.; Kieffer, T.J. Profiling of circulating microRNAs in children with recent onset of type 1 diabetes. JCI Insight 2017, 2, e89656. [CrossRef]

113. Massaro, J.D.; Polli, C.D.; Costa, E.; Donadi, E.A.; Alves, C.C.; Passos, G.A.; Sakamoto-Hojo, E.T.; Crispim, F.; Rassi, D.M.; Pinheiro, D.G.; et al. Post-transcriptional markers associated with clinical complications in type 1 and type 2 diabetes mellitus. Mol. Cell Endocrinol. 2019, 490, 1-14. [CrossRef]

114. Bian, X.; Wasserfall, C.; Wallstrom, G.; Wang, J.; Wang, H.; Barker, K.; Schatz, D.; Atkinson, M.; Qiu, J.; LaBaer, J. Tracking the antibody immunome in type 1 diabetes using protein arrays. J. Proteome Res. 2016, 16, 195-203. [CrossRef]

115. Gan, W.Z.; Ramachandran, V.; Lim, C.S.Y.; Koh, R.Y. Omics-based biomarkers in the diagnosis of diabetes. J. Basic Clin. Physiol. Pharmacol. 2019, 31. [CrossRef]

116. Bloomgarden, Z. Diabetes and branched-chain amino acids: What is the link? J. Diabetes 2018, 10, 350-352. [CrossRef]

117. Sas, K.M.; Karnovsky, A.; Michailidis, G.; Pennathur, S. Metabolomics and diabetes: Analytical and computational approaches. Diabetes 2015, 64, 718-732. [CrossRef] [PubMed] 
118. Nuli, R.; Azhati, J.; Cai, J.; Kadeer, A.; Zhang, B.; Mohemaiti, P. Metagenomics and faecal metabolomics integrative analysis towards the impaired glucose regulation and type 2 diabetes in uyghur-related omics. J. Diabetes Res. 2019, 2019, 1-15. [CrossRef] [PubMed]

119. Li, B.; He, X.; Jia, W.; Li, H. Novel applications of metabolomics in personalized medicine: A mini-review. Molecules 2017, 22, 1173. [CrossRef] [PubMed]

120. Han, L.-D.; Xia, J.-F.; Liang, Q.-L.; Wang, Y.; Wang, Y.-M.; Hu, P.; Li, P.; Luo, G.-A. Plasma esterified and non-esterified fatty acids metabolic profiling using gas chromatography-mass spectrometry and its application in the study of diabetic mellitus and diabetic nephropathy. Anal. Chim. Acta 2011, 689, 85-91. [CrossRef] [PubMed]

121. Thalacker-Mercer, A.E.; Ingram, K.H.; Guo, F.; Ilkayeva, O.; Newgard, C.B.; Garvey, W.T. BMI, RQ, diabetes, and sex affect the relationships between amino acids and clamp measures of insulin action in humans. Diabetes 2014, 63, 791-800. [CrossRef] [PubMed] 